\title{
Mapping Damascus during the First World War. A German- Ottoman Cooperation of Cartography, Archaeology and Military?
}

\author{
Sebastian Willert \\ Boğaziçi University/Technical University Berlin, sebastian.willert@ tu-berlin.de
}

\begin{abstract}
In 1916, the German museum director and archaeologist Theodor Wiegand travelled to the Near East and became "Inspector General of Antiquities in Syria" as head of the 19th Bureau within the IV Ottoman Army under Ahmed Cemal Pasha. In the post-war period the formation was called "German Turkish Commando for Monument Protection", though it consisted mainly of German archaeologists and architects who dedicated themselves to the preservation of antique sites and the collection of antiquities. To investigate the region, the scientists also used Bavarian FlyingDetachments and had aerial photographs taken. The Commando enquired, preserved, and surveyed ancient sites. However, the scientists were also involved in mapping important sites and cities such as Damascus. For this purpose, the archaeologists not only conducted trigonometrical surveys but also used aerial photographs to complement the results taken on the ground.

Against the background of the German-Ottoman cooperation and the involvement of experts such as archaeologists and architects, the paper analyses the - occasionally paradoxical - situation in which the actors dedicated themselves to map the city of Damascus. The contribution answers the question whether the map was developed to visualize ancient buildings and structures in Damascus for preservation purposes or was rather produced due to military objectives. In a helix of overlapping or rivalling aims and agendas of the German and Ottoman archaeology, military and politics it shows attempts, measures and intentions aiming at the production of maps during the First World War.
\end{abstract}

Keywords: Damascus, Ottoman Empire, Cartography, Monument Protection, First World War

\section{Introduction}

"In view of the confusing quantity and irregularity of the streets of Damascus, it seemed urgently desirable to the Etappe-administration to obtain a reliable plan of the old city“ (Wiegand 1921, 5). Three years after the end of the First World War, the German archaeologist and museum director Theodor Wiegand (1864-1936) introduced the fourth volume of "Wissenschaftliche Veröffentlichungen des Deutsch-türkischen Denkmalschutz-Kommandos" (Scientific publications of the German Turkish Commando for Monument Protection) with a reference to the military need to create a map of the old city of Damascus. The work at the core was entitled "Damascus. The Ancient City" and was composed by Carl Watzinger (1877-1948) and Karl Wulzinger (1886-1948). In the aftermath of the War, the German scientists referred to the investigations in Damascus undertaken by members of the so-called "German Turkish Commando for Monument Protection" between October 1917 and June 1918. The very name of the military formation suggests a bilateral undertaking in which German and Ottoman actors came together to dedicate themselves to the protection of monuments in the Ottoman Empire in the midst of the war. As member of the Ottoman government, Ahmed Cemal Pasha (1872-1922) was active in Syria between December 1914 and the end of 1917. In his dual position as Naval Minister and
Commander of the IV Ottoman Army, Ahmed Cemal not only followed military goals to reoccupy Egypt, but wanted to impress upon the Syrian population his perception of the necessity and importance to preserve the Empire's cultural heritage (Theunissen 2016, 228-229, Willert 2019, 44-45; Weber 2009a, 44). Therefore, he initiated measures to protect a choice of antique buildings, mosques, and sites, to promote infrastructural measures and the restructuring of urban space to visualise the presence of Ottoman rule. Eventually, Ahmed Cemal involved Swiss, Ottoman and German experts for the preservation of monuments, the development of infrastructure and the mapping of the region (Kiesling 1919, 34; Weber 2009a, 72; Willert 2019, 45-46). Ahmed Cemal's measures were based on attempts to bind the provinces far from Istanbul closer to the Ottoman capital through centralisation. In the late 19th century, the Sublime Porte had begun to visualize and demonstrate its claim to certain territories, such as the Vilâyet-i Suriye (Vilayet of Syria), through cartography. Infrastructural measures such as the construction of the Baghdad and Hijaz Railways were aimed at facilitating pilgrimages as well as promoting the movement of goods and tourism in the Ottoman Empire and were accompanied by the creation of various maps and their dissemination (Çelik Azarbadegan 2020, 87-88; Low 2020, 253-259). Ahmed Cemal built on the measures and focused on the 
implementation of these very objectives - in addition to the failed military campaigns against the Suez Canal.

The measures and impact of Ahmed Cemal in Syria during the First World War have received some attention in recent years in research. The focus has mostly been on the urban planning policies of the Ottoman Minister of the Navy and Governor General of Syria. Kayalı summarises the connections between the urban restructuring measures and the implicit attempts to manifest centralisation (Kayalı 1998, 225-226). Hudson suggests that Ahmed Cemal's architectural and archaeological patronage was central to his objective of mobilising severely impoverished Islamic capital and consolidating Ottoman control over Muslim Damascus through restoration efforts. Based on the presumption of the Ottoman state's decline, the aim was to secure local support for the Sublime Porte (Hudson 2008, 123). In Hudson's discussion on the urban restructuring measures, Theodor Wiegand and the Commando for Monument Protection are dominant (Hudson 2008, 124126). Çiçek also argues for the transformation of urban space under Ahmed Cemal as a measure that was central to the perpetuation of Ottoman rule in Syria (Çiçek 2014 191-196). But Theunissen criticises ,that Çiçek focuses on modernization and restoration but, unlike Hudson, does not pay attention to the religious-propagandistic dimension of Cemal Pasha's wartime urban works" (Theunissen 2016, 226). In consequence, Theunissen argues, that neither Kayalı, Hudson nor Çiçek would analyse Cemal Pasha's projects in detail and would therefore provide only "general overviews" (Theunissen 2016, 226) that did not examine the events of the First World War or the contextualisation of Ahmed Cemal's urban planning projects and their religious propagandist implications. Moreover, they would emphasize the role of German scholars and marginalise the activities of Ottoman actors. To resolve this asymmetry, Theunissen focuses on three specific projects and investigates ,the renovation of the Takiyya al-Sulaymaniyya and Madrasa al-Salimiyya, the 'sanitization' of the area around the Great (Umayyad) Mosque and the tomb of Salah al-Din, and the construction of the Cemal Pasha Boulevard" (Theunissen 2016, 226). In addition to a chronological study of the projects, Theunissen examines their inherent objectives and concludes, "that all three projects formed part of a programme of Ottomanization and pan-Islamic propaganda which aimed to strengthen Ottoman state authority in Syria and gain popular support among the Muslim population for the empire in times of war" (Theunissen 2016, 226). The project's ultimate goal was to stress "a shared Islamic past and a joint Muslim goal during the war" which was to pave "the way for a (planned but unrealized) common future under Ottoman rule after the war" (Theunissen 226). After Suzanne L. Marchand briefly outlined the activities of the German Turkish Commando for Monument Protection with a complete focus on Wiegand's activities in Syria during the First World War (Marchand 1996, 252-258), Bührig (2016) and Stein (2018) recently highlighted the scientific outcome of German scholars in the Ottoman Empire between 1916 and
1918. I have recently examined the circumstances surrounding the establishment of the Commando and the fundamentally different German and Ottoman objectives at the outbreak of the war (Willert 2016 and 2019).

Against the background of the German-Ottoman cooperation and the involvement of experts such as archaeologists and architects, the paper focusses on the emergence of mapping the damascene old city. I analyse the - occasionally paradoxical - situation in which the actors dedicated themselves to carry out surveys of the old city: What were the motivations of the German and Ottoman actors involved to actually map the city? Was it a mutual undertaking? What sources were used for the mapping processes? For whom was the mapping process designed and who used it in the post-war period?

In the following, I briefly outline the Ottoman attempts to appropriate territories cartographically, which Istanbul considered to be peripheral. Furthermore, I examine how Ahmed Cemal strived to implement these policies by instrumentalising urban restructuring, monument protection and involving German archaeologists. I highlight the mapping of the old city of Damascus as an example of German scholars' contribution and examine not only possible entanglements of Ottoman and foreign cartography of the Ottoman realm but also the influence of the military on the development of maps during the First World War. Briefly, I also address the implications of monument protection in Syria, whereas the focus is on the creation of the map and its underlying implications. Against this background this research ultimately examines the overlapping or rivalling aims and agendas of the German and Ottoman archaeology, military and politics during the First World War. The study shows the interaction of actors involved and provides an interdisciplinary contribution not only to the history of cartography during the First World War and the intertwining of aerial photography, monument protection and mapping, but also to the genesis of German-Ottoman relations and the history of archaeological cooperation and rivalry.

\section{Cartographic Appropriation of the Ottoman peripheral realm}

At the peak of European imperialism and colonialism, the Sublime Porte feared colonisation of territories over which the Ottomans asserted their claim to authority, but which they themselves barely controlled. Therefore, Istanbul considered any interest of a foreign power in Ottoman territory as a potential threat. The Ottoman Empire attempted to counter the situation through reforms and the assertion of Istanbul's influence in previously marginalised regions. The civil war in Damascus and the Lebanon in 1860 unveiled the necessity that some form of internal, administrative unification under Ottoman leadership had to be established to provide Istanbul with the power to control the area. This was to be achieved in 1864 through the establishment of Vilâyet-i Sûriye (engl. roughly: Province of Syria) (Yazbak 2017, 40). Consequently, in the course of reform efforts, 
centralisation measures were to consolidate the Ottoman government in the region through modern bureaucracy and infrastructure as well as a regular tax and a codified legal system. The reorganisation of the provincial administration aimed at urging the Bedouins living in the region to settle down. The fear of colonisation of Ottoman territories also implied a scepticism towards potential European influence on population groups that could hardly be monitored from Istanbul (Köksal 2006, 469). A priority was the protection of the Hijaz region, especially as Istanbul focused on preserving the holy sites of Islam and improving access of pilgrims to Medina and Mecca (Low 2020, 3-5, 109). In this context, extensive Ottoman surveys towards the end of the 19th century gathered information not only about natural features, routes of railway lines and the road network, but also about religious affiliations of the local populations. However, it was only after the Young Turk revolution in 1908 and the introduction of the Harita Kurulu (Council of Cartography) in 1909 that these religious affiliations appeared in maps in the form of visual representation. As Çelik and Azarbadegan explain, Harita Kurulu's primary goal was "to produce a map of the entire Ottoman lands", while its secondary goal was to carry out "geographic research from the ethnographic perspective on Ottoman lands" (Çelik/Azarbadegan 2020, 98).

The First World War led to an intensification of the cartographic appropriation of space in the Middle East. It was not only the British army, with the help of aviators, that drew up maps of Egypt in 1915, and in the further course of the war also from the Sinai and of the regions around Gaza and Mesopotamia (Hamshaw 1920, 351). Along with German troops, German specialists had also been sent to the Ottoman Empire. In Mesopotamia, the geographer and explorer Albert Tafel (1876-1935) mapped the Euphrates in 1917/18 in cooperation with Hellmuth von Mücke (1881-1957) (Fickeler 1935, 483; Kartographische Abteilung der Preußischen Landesaufnahme: Map of the Euphrates from Dscherâblus to Fellûdscha, 1:400.000, Berlin 1917/18.). Hans von Ramsay (1862-1938) produced a map of Syria between 1915 and 1918 on behalf of the IV Ottoman Army, which was made available to the Cartographic Department of the German General Staff. ${ }^{1}$ In January 1916, the invoice for the "Map of the Turkish-Egyptian Border Area between the Hedzhaz Railway and the Suez Canal 1:250 000"2 was sent to the Reichskolonialamt (Imperial Colonial Office), whereupon, by 1918, a series of maps from the Ottoman Empire was sent by the Kartographische Abteilung der Königlichen Landesaufnahme (Cartographic Department of the Royal Land Survey) to the Imperial Colonial Office. ${ }^{3}$ German individuals or units were ordered to map various parts of the Ottoman Empire. In addition to the Euphrates or Sinai region, for example, surveys were also launched in Baghdad, Erzurum and Nazareth (Alt 1919,

\footnotetext{
${ }^{1}$ Bundesarchiv (BArch), R 1001/6668, fol. 4, Joachim to Solf, Berlin, 25 August 1915; Ibid., p. 5, State Secretary of the German Imperial Naval Office to Imperial Colonial Office, Berlin, 30 August 1915.
}

102; Espenhorst 2016, 117-118). From 1915, the production of a "Map of Mesopotamia at 1:400,000" as well as a "Brief Military Geographical Description of Mesopotamia" was to begin; by autumn 1917, eleven of the envisaged twenty-four sheets of the map had been produced (Espenhorst 2016, 117-119). German surveying operations were not limited to the Ottoman Empire. As the Chief of War Survey, Siegfried Boelcke, explained in 1920: „Not only were German surveying sections located along all French and Russian fronts, they were also positioned in Galicia, the Carpathians, Romania, Italy, Macedonia and Palestine in support of German, as well as Austrian, Hungarian and Turkish troops, [...]." (Boelcke 1920, 7; also quoted in Espenhorst 2016, 97).

However, not only foreign powers - whether hostile or allied - were interested in maps of the Ottoman territory. After the outbreak of the war, the Cartography Department of the Ottoman Army also continued its fieldwork and mapped the territories of the Ottoman Empire. The process began in Rumeli (Rumelia) and Anatolia and was eventually extended towards Gaza. With the help of Ahmed Cemal, the towns and cities of Gaza, Jerusalem, Jaffa, Nablus and Haifa, among others, were mapped and printed at a scale of 1:200,000 (Çelik/Azarbadegan 2020, 100).

The work Filistin Risalesi (Treatise on Palestine), published during the First World War, played a significant role. Mersinli Mehmed Cemal Pasha (1875-1941), according to his military rank known as Küçük Cemal Paşa (engl.: Little Cemal Pasha), as Commander of the VIII Ottoman Army published the booklet together with Ahmed Cemal in 1915 (Tamari 2011a, 32-33). Designed for military use, Filistin Risalesi contained historical, demographic, ethnic, religious, and infrastructural information as well as geographical specifications, for example on water resources or agricultural production in the region (Çelik/Azarbadegan 2020, 98). Special sections were also devoted to the mountains and valleys in the regions considered to be Palestine (Akka, Jaffa, Jerusalem and Nablus) (Tamari 2011b, 6). In a historical section, entitled "Filistin Tarihi" (Palestine History), the Filistin Risalesi listed significant events of the past from the authors' point of view and referred to "Canaanite, Philistine, Hebrew, Babylonian, Arab and Islamic conquests“ (Çelik/Azarbadegan 2020, 98; Filistin Risalesi 1331/1915).

In addition to the Seljuk conquest and the conquest under Sultan Selim I in 1517, the Napoleonic campaign of 1799 and Ibrahim Pasha's conquests at the end of the 1830s were also highlighted. Furthermore, monuments in the region were listed and information was provided on their current condition. The booklet not only mentioned main monuments, such as the Kubbet'üs-Sahra (Dome of the Rock) and the Kutsal Kabir Kilisesi (Church of the Holy

\footnotetext{
${ }^{2}$ BArch, R 1001/6668, n. pag., Publisher Dietrich Reimer (Ernst Vohsen) to Imperial Colonial Office, Berlin, 15. Januar 1916.

${ }^{3}$ BArch, R 1001/6668, p. 17-17v., Cartographic Department to Imperial Colonial Office, Berlin, 26. April 1918.
} 
Sepulcher) in Jerusalem but listed also various smaller architectural remains. As an example, Cisr-i Benat-1 Yakub (Daughters of Jacob Bridge) was mentioned as was Safed, which was highlighted for its importance to the Jewish population (Filistin Risalesi (1331/1915). Filistin Risalesi also provided an insight into the network of roads and indicated water resources. Finally, three maps complemented the geographical, historical and geological descriptions. One map showed the altitude distributions and heights in the Palestinian territory, another showed ethnic diversity, and finally one map indicated the railways and main transport routes (Çelik/Azarbadegan 2020, 9899).

The Yıldırım Ordusu (Thunderbolt Army Group), which was dominated by German officers (the leading positions in the army group included sixty-five German and only nine Ottoman officers), also compiled some maps based on their operations during the First World War (Çelik/Azarbadegan 2020, 100). The army group focused on two scales: large overview maps that served as orientation in the region and more detailed regional maps that provided information on individual military operations. One of the maps produced, called "Filistin yol haritası" (Palestine Road Map, fig. 1), included not only land routes but also the railway connections in Palestine. The territory depicted in the map extends from Şam (Damascus) in the northeast to Sayda (Sidon) on the coastline in the far northwest. In the east, the Hedjaz Railway's north-south-course forms the border of the map, while to the west the Mediterranean Sea constitutes a natural boundary. Towards the southeast, the last stations of the Hedjaz Railway, Katrana and Qal'at al-Hiza, are listed, while the map's foothills to the southwest include Chan Yunis and El Arish. The Filistin yol haritası not only indicated the region's railway network and main road system, but also listed names of smaller settlements, larger towns and cities. Of particular interest is that the map legend also lists "eski harabeler" (engl.: old/antique ruins). However, the map does not provide a complete overview of the ancient sites located on the territory depicted. The nameless records of ancient sites are concentrated in the south-western area, while nearly any sites in the north are left out entirely.

It is evident, that from 1916 onwards, however, antiquities and ancient sites in the territory came to the fore of Ahmed Cemal's attempts to tie the area he ruled to Istanbul and, as an Ottoman territory, to link it culturally to a construction of an Ottoman identity. Through the distribution of the booklet as well as the maps, Ottoman soldiers and officers were educated about regional diversities, geographical features and finally important ancient sites.

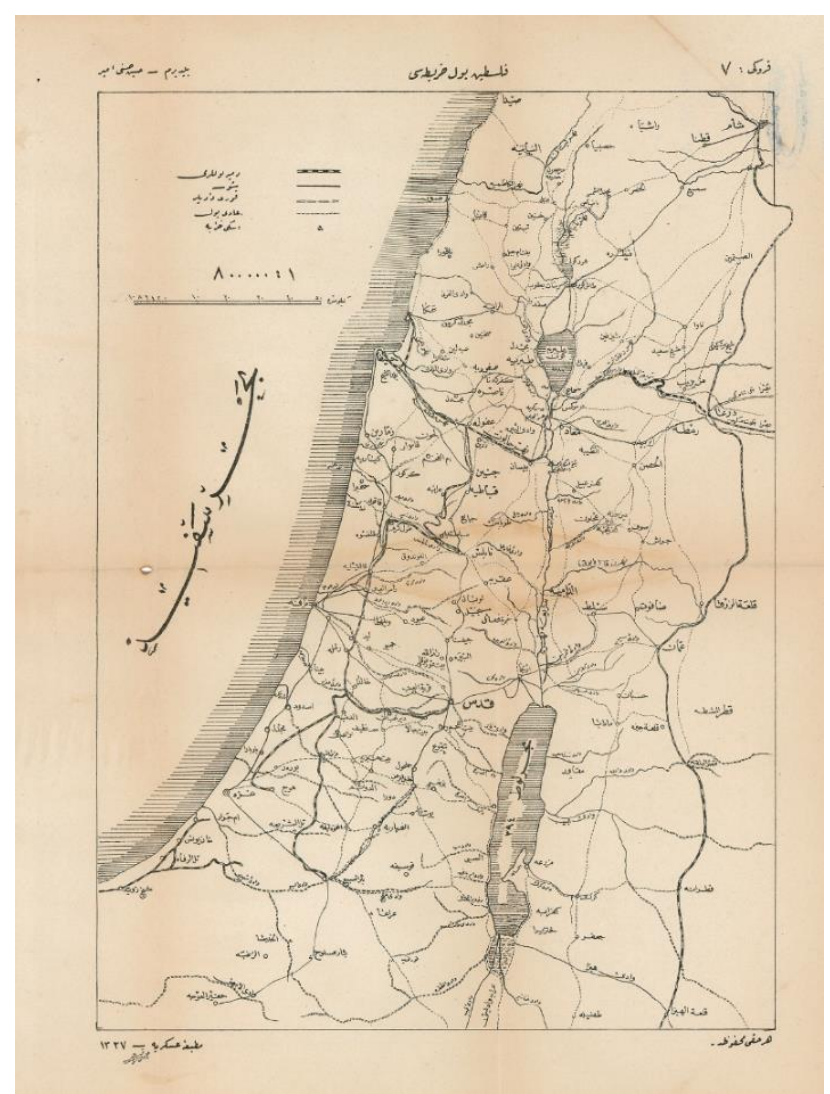

Figure 1: Filistin yol haritas1 (Palestine Road Map). The Map reaches from Sidon and Damascus in the north to the southern border of the District of Jerusalem. In addition to the main traffic routes such as the railway lines and the connecting roads, ancient sites are also marked in the south-western part of the map. (C) İ.B.B. Atatürk Kitaplığı, Fahreddin Türkkan Paşa koleksiyonu, Measurement: 46x34 cm; Scale 1: 800.000 Hrt_011229.

\subsection{Antiquities and the Ottomanization of Syria}

On 8 December 1914, shortly after the Ottoman Empire entered the First World War, Ahmed Cemal Pasha took over as commander-in-chief of the IV Ottoman Army and henceforth acted as governor-general of Vilâyet-i Sûriye. Between 1914 and 1917, he effectively ruled the territory under his control and, following unsuccessful campaigns against the Suez Canal in 1915 and 1916, attempted to consolidate Ottoman rule in a region, which was marked by internal unrest. The Ottoman identity was to be imposed on the diverse and multi-ethnic population, which government circles considered to be rebellious. With the use of extreme force and an authoritarian style of rule. Ahmed Cemal's presence had an impact on the urban space of several cities and towns in the region. With financial support of the Evkaf-1 Hümâyun Nezâreti (engl.: Ministry of Endowment), Ahmed Cemal tried to increase the visual presence of the Sublime Porte within the Vilayet of Syria through restoration (Theunissen 2016, 227). The governor-general assigned the Ottoman architect Mehmed Nihad Bey (1880-1945) with the task to restore the large multifunctional complex of the Süleymaniyye, which was significant within the yearly hajj. The complex included both, the Takiyya al-Sulaymaniyya and the Madrasa alSalimiyya (Cengizkan 2009, 187-188; Theunissen 2016, 
227, 229, 259-260). According to Theunissen, the ruinous condition of the complex symbolised the state of the Ottoman Empire for Ahmed Cemal, and thus stood ,symptomatic for the lack of state authority in Syria" (Theunissen 2016, 229). In the context of an innerOttoman debate on the construction of an Ottoman identity and the references to the - especially Islamic - past (Çelik 2011, 469; Shaw 2003, 208-217; Shaw 2007, 243-279; Theunissen 2016, 229), Ahmed Cemal underlined the importance of the (Islamic) relics and symbolised awareness of the need to preserve a national heritage by initiating various restoration processes in the Vilâyet-i Sûriye.

Modernization measures served to increase tourist appeal and simplify the surveillance of the urban population. To this end, the traditional narrow streets and dense urban development were to give way to wide boulevards, such as the "Cemal Paşa Boulevard" in Damascus, which Ahmed Cemal named with pride after himself (fig. 2) (Cemal 1922, 366; Theunissen 2016, 256). Paradoxically, significant parts of the city - not only residential buildings but also Arab mosques, fell victim to the road extensions and reconstruction measures. Ottoman buildings, however, were saved from demolition (Theunissen 2016, 253-254).

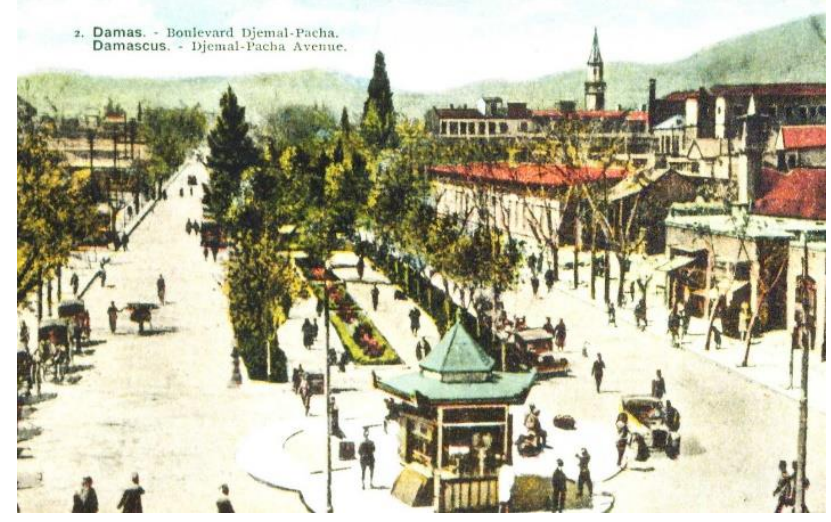

Figure 2: View of the wide boulevard that Ahmed Cemal had built in Damascus on the European model and named after himself (undated postcard, ca. 1920).

Simultaneously, the expansion of communication lines and infrastructure maximized the visibility of Ottoman influence in the region (Çiçek 2014, 191). Early in the war, Ahmed Cemal hired Swiss architects to restructure the inner cities according to modern European ideals and tried to enlist a German landscape architect ${ }^{4}$ and an agronomist ${ }^{5}$ for his projects in Lebanon. However, Ahmed Cemal not only pushed modernization, but also turned his attention to the preservation of cultural heritage. With financial support from the Evkaf-1 Hümâyun Nezâreti, he restored the Selim Mosque in Damascus, located on Cemal Paşa Boulevard. He also sponsored the restoration of the tomb of Muhiyddin al-Arabi, one of the most prominent figures

${ }^{4}$ Bundesarchiv-Militärarchiv (BArch-MA), RM 40/725, p. 18, Hans Humann to Ahmed Cemal, Istanbul, 4 February 1916.

5 BArch, N 1581/71, n. pag., Cable Julius Harry LöytvedHardegg to German Foreign Office, Damascus, 19 January 1916. in Sufi history, built by Selim II (1524-1574). Other plans included clearing the walls of the Al-Aksa Mosque in Jerusalem of older buildings, restoring the Jerusalem Citadel, and eventually using it as a local museum. In Beirut, telegraph and post offices were built in addition to a palace, while in Aleppo some parts of the citadel were to be restored (Çiçek 2014, 195-196). In 1915, in order to counterbalance the French schools that dominated the region, and in particular to challenge the hegemony of the Islamic universities of British-dominated Egypt, Ahmed Cemal seized a French Crusader church and founded Salah al-Din University in its complex. (Theunissen 2016, 250). By preserving the ancient remains and promoting the accessibility of the historical-cultural monuments of the entire region, Ahmed Cemal sought to use the relics of the past in the sense of an identity-forming cultural heritage. Ancient, Byzantine and Islamic-Arabic buildings were taken into account, as well as buildings from the Ottoman era. Ahmed Cemal saw the conglomerate of remains as a component of Ottoman identity and heritage (Çiçek 2014, 196).

Ahmed Cemal's measures took on a curious shape at times. The commander of the 1st Ottoman Expeditionary Corps, Friedrich Kreß von Kressenstein (1870-1948), reported from the desert: "As we waited desperately in the desert for bread and barley, the eagerly awaited camel convoy brought us, instead of food, daintily hewn stones with which we were to decorate the water points we had opened to immortalise the name of Achmed Dschemal. In the large military hospitals of Birseba, the sick and wounded had to suffer severe thirst, because Dschemal had taken it into his head to create a city garden, and the available water was necessary for his plantations. The urgently needed hospital buildings in Hafir el Audja were left undone for days and weeks because all the workers were used to erect a monument to Dschemal Pasha. While we were in desperate need of workers at the front to further our railway and road construction and staging facilities, in Damascus, Jaffa and Beyruth, Dschemal had entire districts demolished and built boulevards bearing his name.” (Baumgart 2020, 293)

In order to realise his ideas of a Vilayet-wide monument protection, Ahmed Cemal sought out experts to support him. In a letter to the head of the German military mission in the Ottoman state, Liman von Sanders (1855-1929), Ahmed Cemal reports about numerous scientifically and artistically valuable antiquities in Syria. Because of this, "I [Cemal] have been looking for a suitable man for a long time who could organize a supervisory body for the preservation of these monuments in order to be able to make plans and drawings for a scientific publication. By a happy coincidence I made the acquaintance of Captain Dr Wiegand, who had hitherto been sent as chief of a military transport." The meeting with the German archaeologist

${ }^{6}$ Bayerisches Hauptstaatsarchiv (BayHStA) Abt. IV Kriegsarchiv, MKr. 1956, n. pag., Translation of Ahmed Cemal's Letter to Liman von Sanders, Damascus, 10 February 1917. 
Theodor Wiegand consequently offered Ahmed Cemal the opportunity to engage a classical archaeologist as an expert for his purposes. But how had the German museum director come to Damascus in the midst of the war as the head of a troop transport and how did the "happy coincidence" of the meeting with the Ottoman government member come about?

\subsection{German Scientists in Syria}

At the outbreak of war, Theodor Wiegand was in Berlin and tried in vain to enlist for active army service. After he was finally assigned to the Berlin command as an adjutant on 30 November 1914, he was seconded to the War Press Office of the General Staff in September 1915 (Watzinger 1944, 271-274; Willert 2019, 45). Unhappy with the activity in Berlin, Wiegand tried to obtain a different detachment. On 12 June 1916, through the general director of the Berlin museums, Wilhelm von Bode (1845-1929), he asked the Ministry of Culture to place him under the command of the military authorities in the Ottoman state so that he could "make scientific observations in a soldierly capacity in the entire area of the Turkish operational area."7 Wiegand at that time saw the opportunity in "contrast to the paper economy" participate in the war effort and commented a week later, "I urge to get to Turkey as soon as possible."

The War Ministry agreed to the museum staff's wish, informed the relevant German military authorities, and Wiegand received support for the dispatch to the Ottoman Empire. However, the Germans did not consider a possible cooperation with Ottoman authorities. On the contrary, about a month before his departure from Berlin to Istanbul, Wiegand wrote in his diary: "According to recent determination of the War Ministry, in order to conceal my detachment to Turkey \& my real objectives, I am ordered to lead a troop transport for the Suez Canal." ${ }^{10}$ Instead of seeking cooperation with the director of the Müze-i Hümayun (engl.: Imperial Museum), Halil Edhem Eldem (1861-1938), or Ottoman authorities in general, not only the dispatch of the German museum director but also the objective of his trip, i.e. to conduct scientific research, was kept secret. On 25 August 1916, a replacement transport of the so-called "Pascha formation" led by Theodor Wiegand left Berlin and arrived in Istanbul on 2 September. The architect and lieutenant of the reserve, Karl Wulzinger (1886-1949), and the interpreter, professor of archaeology and Landsturmmann Carl Watzinger (1877-1948) accompanied Wiegand. After the arrival of the transport at its destination in southern Palestine, the German scientists were integrated into the staff of Colonel Friedrich Kreß von Kressenstein in October 1916 (Baumgart 2020, 607; Willert 2019, 46). The latter obtained permission from Ahmed Cemal for Wiegand to make topographical surveys. According to Watzinger's account, during the initial surveys within the IV Army's area of operations,

\footnotetext{
${ }^{7}$ Deutsches Archäologisches Institut, Archiv der Zentrale (DAIZ-AdZ), Collection Wiegand, Box 23, n. pag., Diary Theodor Wiegand, Entry of 12 June 1916.
}

Wiegand became aware of the widespread and extensive destruction of antiquities and antique sites. In consequence, the archaeologist saw the need for the establishment of an efficient monument protection authority in the Ottoman Empire. Under the impression that such a commitment could not be concealed, Wiegand now sought direct contact with Ahmed Cemal to win him personally for the project (Watzinger 1944, 289). Consequently, the German actors tried to attribute the initiative of establishing a department for the preservation of monuments in the Ottoman Empire to their commitment. They did not name any Ottoman attempts regarding the protection of monuments and the preservation of ancient sites.

With the help of Kreß von Kressenstein and through the German consul in Damascus, Julius Harry LöytvedHardegg (1874-1917), who was acquainted with the Ottoman commander, Wiegand was introduced to Ahmed Cemal and achieved unexpected success. Wiegand reported about the meeting: "Suddenly Djemal Pasha says: I would like to put all the monuments of the country under special supervision. [...] Then I would create the position of Inspector General of Antiquities for Syria and Palestine - honorary for you [Wiegand] - and I would order that you be assigned in this position to my headquarters and specifically to my person. I would wish that under your direction you record the Turkish and the older Islamic buildings in Damascus and Aleppo, but also all other important buildings. The whole thing should then be published" (Wiegand 1985, 198-199).

As the "19th Bureau in the Supreme Command of the Syrian West Arab Army", which probably Wiegand named after the war "German Turkish Commando for Monument Protection", was established on 1 November 1916, it was directly subordinated to the staff of the Supreme Commander of the IV Ottoman Army Ahmed Cemal. It operated in the region of Syria, Palestine, Transjordan as well as Lebanon (Wiegand 1919, 174). In the preface of the work "Ancient Monuments from Syria, Palestine and Western Arabia", published in 1918, Ahmed Cemal outlined the objectives of the formation's establishment. These lay in " 1 . creating a reliable monitoring body for the preservation of artistic monuments. 2. preventing harmful new construction inside and in the immediate vicinity of old structures, cleaning up the ruins, prohibiting the population from using the ruins as building materials. 3. improvement of the access roads to the antique sites and creation of suitable accommodation to facilitate the visit for locals and foreigners. 4. collection of antiquities within the army zone." (Ahmed Cemal 1918, n.p.). While the "German Turkish Commando for Monument Protection" was not yet mentioned by name in this publication, the term only appeared in the post-war "Scientific Publications of the German Turkish Commando for Monument Protection" published in

\footnotetext{
${ }^{8}$ Ibid., n. pag., Entry of 29 April 1916.

${ }^{9}$ Ibid., n. pag., Entry of 18 June 1916.

${ }^{10}$ Ibid., n. pag., Entry of 16 July 1916.
} 
Germany between 1920 and 1926 (Wiegand 1920). However, Wiegand did not only want to use his stay in Syria for monument protection and scientific research, but he also saw it as an opportunity to discreetly identify potentially lucrative archaeological sites and objects for the Royal Museums of Berlin. Shortly before setting off for Palestine, Wiegand wrote to Wilhelm von Bode: "Of course, in the current confederative relationship, there can be no talk of a prey à la Napoleon I, but a great deal could come out of it, which is welcome to us." unveils the museum director's agenda and sets out why no contact was made with Ottoman authorities. Initially, the focus was not on monument preservation activities, but rather on a survey of potential acquisitions and excavation areas for the Berlin museums. As Oliver Stein already concludes, the originally intended plan could not be pursued to the desired extent during the war (Stein 2018, 311). Nevertheless, between 1916 and 1918, Wiegand and his colleagues made various excursions in the operational area of the IV Army, sent reports including recommendations on conservation and protection measures to Ahmed Cemal, and collected material for publications. The formation's extensive excursions were undertaken by the German scientists together with Ottoman soldiers. Occasionally, investigations were also carried out alone in the company of a soldier or someone local who was familiar with the site. ${ }^{12}$

Depending on the duration of the stay on site, the detailed scientific documentation of the monuments as well as the analysis of the building structure and, in part, a reconstruction of the site or individual buildings took place. In some cases, provisional monument preservation measures were carried out, such as the stabilization of the triumphal arch in Palmyra. For the first time, overall plans of individual city complexes or selected urban areas, such as Damascus and Petra, were produced (Bührig 2017, S. 189). In the following, I will focus on the mapping of Damascus and examine the extent to which the creation of the city map was a German-Ottoman undertaking and what the objectives of mapping the old city during the First World War were for the actors.

\section{Mapping Damascus, 1917-1918}

In 1925, the German theologian Gustaf Dalman (18551941) published a compilation of aerial photographs taken by Bavarian Air-Detachments during the First World War under the title "Hundert Deutsche Fliegerbilder aus Palästina" (engl.: One Hundred German Aerial Photographs from Palestine). Dalman linked the value of the aerial photographs to the 6th century Madaba mosaic (fig. 3), which depicts Palestine, the Egyptian desert, and the Nile delta (Dalman 1925, 3-4). Thus, the theologian intertwined the significance of German pilots' and scientists' work in Palestine during the First World War

\footnotetext{
${ }^{11}$ Staatliche Museen Berlin-Zentralarchiv (SMB-ZA), NL Bode 5885/3, Wiegand to Bode, Berlin, 2 June 1916.

12 DAI-Z-AdZ, Collection Wulzinger, Box 1, Wulzinger's Notebook No. 17, Trip to Palmyra and Damascus, p. 1, Entry of 1 April 1917.
}

with that of the oldest surviving original of a cartographic representation of the so-called Holy Land and Jerusalem in particular. However, Dalman also pointed out that aerial photograph's role in producing maps could only contribute complementary to surveys undertaken on the ground (Dalman 1925, 4). Watzinger and Wulzinger carried out this work in Syria.

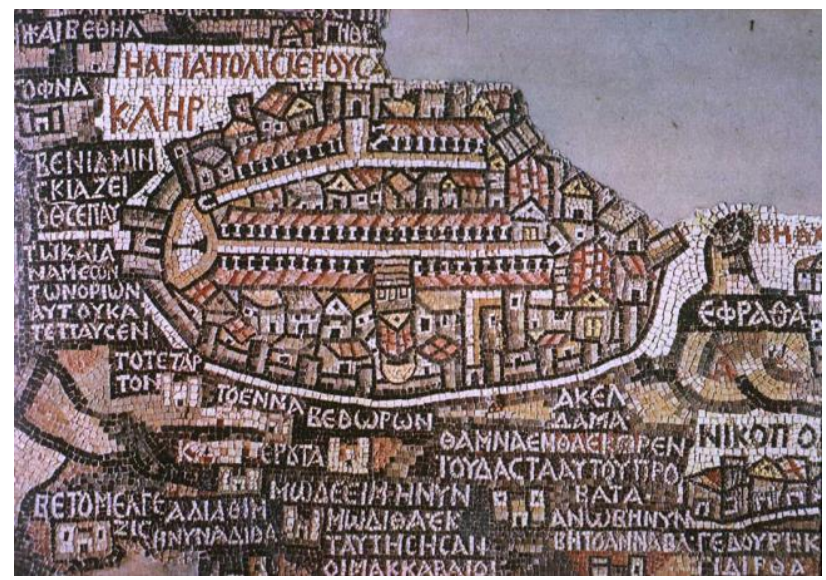

Figure 3: The depiction of Jerusalem on the 6th century map-like Madaba Mosaic. Wikimedia Commons.

In his diary, Watzinger considered the work in Damascus as of unique potential that had to be taken advantage of: "In peace, you will never again have such an opportunity to work; for this reason alone, you have to take as much with you here as you can."13 Between October 1917 and June 1918, the members of the 19th Bureau surveyed and mapped the Old City of Damascus. They used "the opportunity both for the verification of the previous topographical research and for a planned individual survey of the Greco-Roman, Byzantine as well as Islamic monuments and building remains" (Wiegand 1921, 5). Watzinger and Wulzinger wanted to take advantage of the possibility of working in the city "to record all the observations about ancient architectural remains as well as about the remarkable Islamic monuments on a large-scale map and thus possibly bring them into mutual connection" (Watzinger/Wulzinger 1921, 1). For this purpose, the archaeologists wanted to use maps that had already been prepared but considered them insufficient because they showed distortions and only depicted a small part of the old town in detail. Nevertheless, several existing maps, like "Tramways et Eclairage électriques de Damas, Ville de Damas. Plan général. Relevé en 1908" (Damascus Tramways and Electric Lighting, City of Damascus. General plan. Survey in 1908), which mapped the damascene electrification based on the tramway lines, were studied. The scientists soon realized, however, that the plan had not been drawn up on the basis of triangulation: "Individual quarters agreed well with each other, they had been visibly surrounded by polygons; but

${ }^{13}$ Universitätsarchiv Tübingen (UAT), 546/2, p. 141-n. pag., Diary of Carl Watzinger, Entry of 5-13 February 1917. 
when these individual parts were joined together, significant errors occurred, above all, swings. Thus, the plan could only provide us with valuable services as a hand outline" (Watzinger/Wulzinger 1921, 1).

A complementary source was the map of a German officer, which he drew prior to the outbreak of the war. During "smaller military exercises in the Damascus area" it was noticeable for the German military that "a map on a suitable scale was not available." (Schäffer 1919, 188). Europeans living in Damascus also expressed to the German colonel and former Ottoman lieutenant colonel and inspector of the infantry of the VIII. (Syrian) Army Corps, E. Schäffer, their wish to have access to a map for tourist trips. Consequently, Schäffer prepared a plan of the surrounding area of Damascus at a scale of 1:25,000 between January and October 1913 (Schäffer 1919, 188).

The material available to the German archaeologists in 1917 was not sufficient for a precise mapping of the old city. Already at the beginning of Watzinger's and Wulzinger's activities in Damascus, the need for precise surveying of the city was apparent. To map antique urban structures and objects within the city, a detailed map was needed. The measurements taken on the ground were to be completed with the help of aerial photography.

\section{1 "Aerial photography in the service of archaeology in the midst of war!"}

After Watzinger arrived in Damascus together with Wulzinger on 21 January 1917, they found Wiegand in an airmen's home near „Bêt Tûmê”. ${ }^{14}$ That house was to become the base for the scientists of the formation, which they initially shared with other members of the German military mission - notably also with pilots of the Flying Detachments stationed in or near Damascus. A close contact developed between the scientists and the airmen while their conversations revealed the importance of aerial photography for mapping processes. In consequence, Wiegand, Watzinger and Wulzinger also realised the possibility of using aerial photographs to support their monument conservation, archaeological or topographicgeographical work. Wiegand and Richard Falke (*1892) agreed that the aviator should take some pictures for the formation. After Falke had handed over the first recordings to the scientists, Watzinger noted in his diary: "We have now received magnificent aerial photographs of the ancient desert cities, which First Lieutenant Falke made at Wiegand's request. On this occasion, a hitherto completely unknown city has come to light, and further photographs are to follow. The photographs are so excellent that they can be used to draw a map of the city and the ground plans of the houses." 15 The scientists immediately realised the significance of aerial photographs, whereupon they were even allowed to take part in a flight over Damascus: "Through Lieutenant König and Lieutenant Lederer, we made a flight over Damascus together and in the process

${ }^{14}$ UAT, 546/2, p. 129-131., Diary of Carl Watzinger, Entry of 21 January 1917. Watzinger referred to Bayt Mitrī Afandī Shalhūb, the former house of the Spanish Crown, also known as Bayt Dādā. (Weber 2009b, 550). also took four photographs for ourselves, which we can make use of. Aerial photography in the service of archaeology in the midst of war!"16

Various Bavarian Flying Detachments were stationed and active in the Ottoman Empire during the First World War. While Dalman referred only to aerial photographs of the Bavarian Flying-Detachment 304 (Bayerische FliegerAbteilung 304) in his publication (Dalman 1925, 120; Waldenfeld 1920), Watzinger and Wulzinger mentioned that "[a]erial photographs from Section 305 were also useful here, especially in locating the narrowest alleys, which could often only be reached through a gate $[\ldots]$ ", (Watzinger/Wulzinger 1921, 2). The two scientists not only gave the indication of the Flying-Detachment they relied on for their purposes, but at the same time also in what way they profited from the aerial photographs. Thus, they used aerial photographs to evaluate the measurements obtained on the ground in order to be able to draw an accurate plan of the old town. An illustrative example is a photograph from the 1921 publication of Watzinger and Wulzinger. Almost in its centre, the aerial photograph depicted (fig. 4) clearly shows the location of the Umayyad Mosque as well as the adjacent urban structure of the Old City's neighbourhoods.

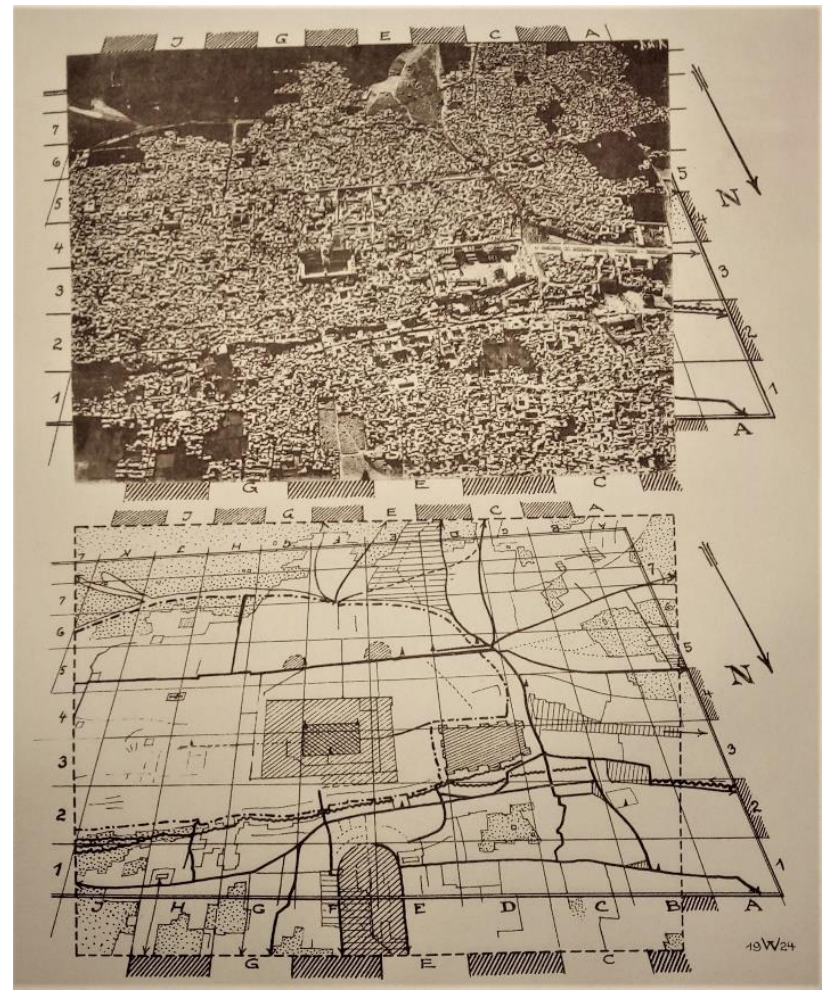

Figure 4: Damascus from the north. Aerial photography and Map (Wulzinger/Watzinger 1924, fig. 59).

The image illustrates that Watzinger and Wulzinger took the aerial photograph as a template, classified it in their grid pattern and transferred it to the city map.

${ }^{15}$ Ibid., p 141-n. pag., Diary of Carl Watzinger, Entry of 5-13 February 1917.

${ }^{16}$ Ibid., 546/2, p. 141-n. pag., Diary of Carl Watzinger, Entry of 5-13 February 1917. 


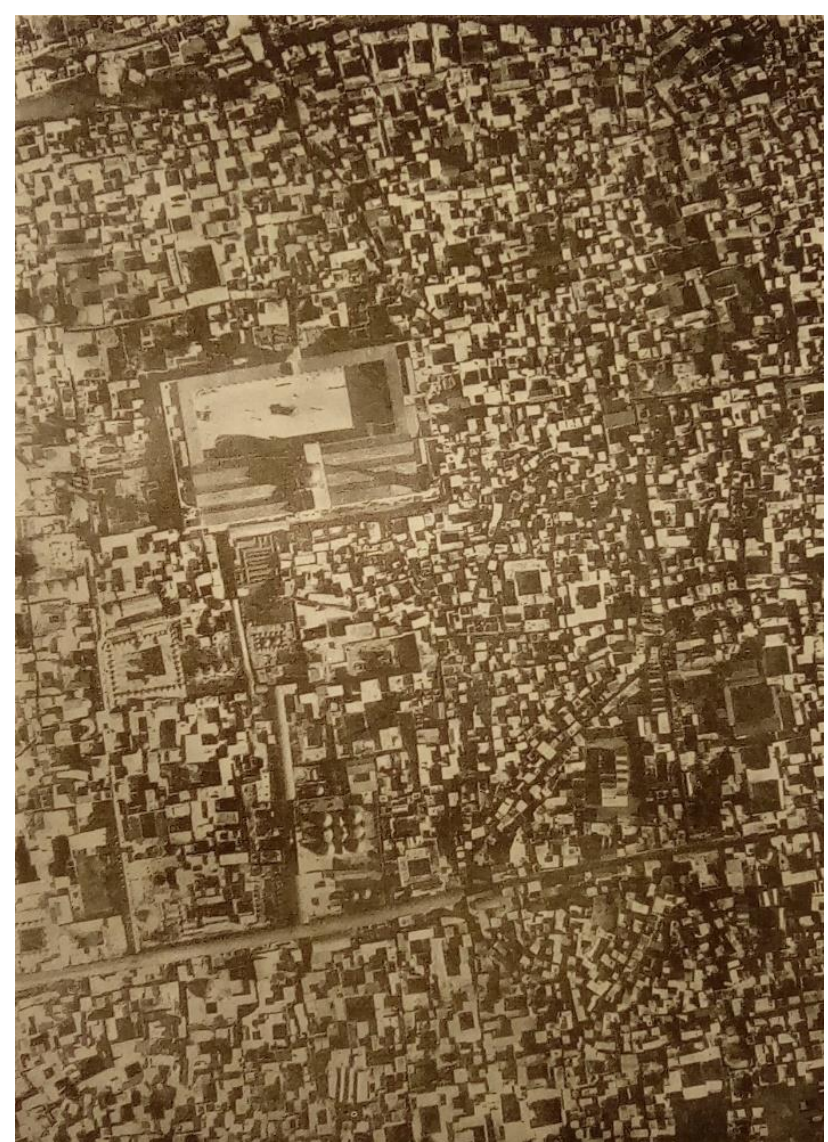

Figure 5: Aerial photograph from the publication Damascus showing the district south of the Omayyad Mosque with the Straight Street mentioned by Watzinger/Wulzinger (Watzinger/Wulzinger 1921, 45, fig. 31).

Not only for the drawing of the city map, but also as a supplement for the architectural surveys of the UmayyadMosque, Watzinger and Wulzinger completed their research with the help of aerial photographs (fig. 5). After the war they compared and combined the results taken on ground with these from the air and included them in their publication. Not only the area around the mosque was considered (fig 6), but also the mosque and its inner courtyard (fig. 7). Detailed drawings illustrate buildings of particular interest for the scientists like the UmayyadMosque and ground plans.

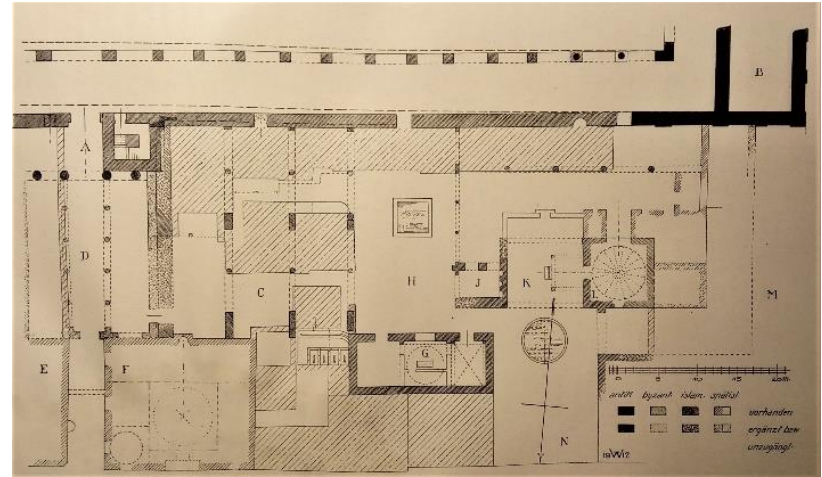

Figure 6: Area around the Umayyad-Mosque (1: 400) (Wulzinger/Watzinger 1924, 64, fig. 7).

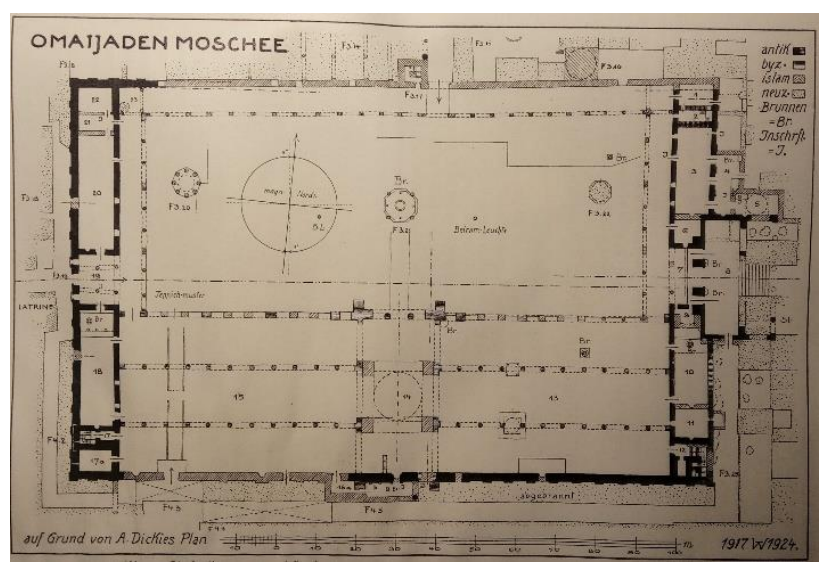

Fig. 7: Umayyad-Mosque on the basis of existing plans and own measurements; 1:1200 (Wulzinger/Watzinger 1924, 144, fig. $50)$.

Aerial photographs taken from higher altitude clarified the dimensions of contemporary Damascus (fig. 8). The photograph of bird's-eye view, Dalman published in 1925, indicates the expansion of damascene urban space to the north, west and south in the form of developing suburbs (Dalman 1925, 106). The Umayyad Mosque stands out in the centre. The photograph gives an idea of parts of the city wall.

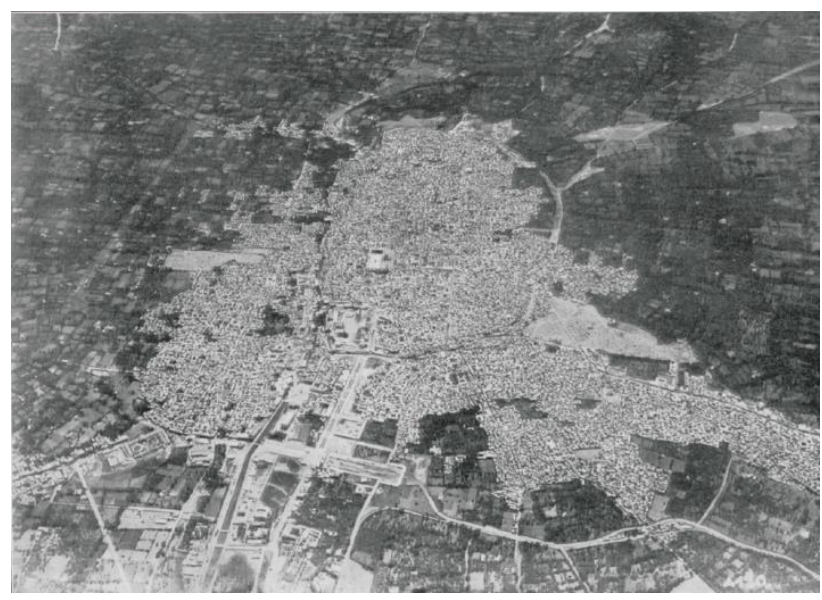

Fig. 8: Dalman subtitled the aerial photograph "Damascus and its Gardenland". The photograph was probably taken by the Bavarian Flying-Detachment 305 (Dalman 1925, 107, fig. 98).

In their research, Watzinger and Wulzinger concentrated on the area of the damascene old city intra muros. The aerial photographs entered their publications and complemented their topographical studies (Watzinger/Wulzinger 1921; Wulzinger/Watzinger 1924; Trümpler 2008, 474-483).

\subsection{Fieldwork and Surveys on the Ground}

Watzinger and Wulzinger did not only draw the map of Damascus. Their studies included examining the urban structure and drawing detailed architectural surveys of quarters, important sites and objects. Furthermore, they examined urban neighbourhood communities - "Stadtviertelgemeinschaften (mahallât)" (Wulzinger/Watzinger 1924, 32). They described how decades before Watzinger's and Wulzinger's presence, access to the 
individual quarters was regulated by gates that were now off their hinges. Modern breakthroughs also caused a softening of the once strict separation (Wulzinger/Watzinger 1924, 32). The study of neighbourhood structures served their interest in the genesis of urban space. As already mentioned, Watzinger and Wulzinger focused on the investigation of ancient structures. In addition to individual ancient remains, they tried to trace and record the ancient street network as well as the ancient division of the city and its effects on the contemporary urban structure. In this regard they wrote in 1921: "Here and there, in the straight course of modern alleys, one believes to still feel the after-effect of the ancient system; also, pieces of work, reused ashlars and parts of columns give some clues" (Watzinger/Wulzinger 1921, 54).

The scientists had difficulties in carrying out the triangulation, as it was necessary to find a "level base, not disturbed by traffic and sufficiently long, from the ends of which several suitable targets could be seen." (Watzinger/Wulzinger 1921, 1-2). Eventually, Watzinger and Wulzinger had chosen "a footpath crossing the silent cemetery at Bâb Arslân” (Watzinger/Wulzinger 1921, 2). The path developed into the first main survey point and became the starting point for the map making: "This basic route, measured six times with a steel tape measure, resulted in the length of 73,688 m. It descends from north to south by $1.295 \mathrm{~m}$, so that in reduced length it was 73.677 $\mathrm{m}$. From here, among others, five points were determined, namely 1. the top of the minâre [minaret, SW] on Bâb Tuma, 2. the top of the minâre in the Christian quarter, 3. the top of the turret of the Ananias chapel, 4. the top of the minâre Bâb esch-scharki and 5. the lightning rod on the factory chimney outside the Bâb esch-scharkii” (Watzinger/Wulzinger 1921, 2). Additionally three metering points were erected on the minarets of Sadat esSenebîje and el Mu'allak and finally one on the top of the house Dada which used to be the Spanish Consulate in Damascus and served as accommodation for the members of the formation Wiegand in 1917/18. Watzinger and Wulzinger defined further 30 points which were distributed over the damascene old city's urban area. Measurements were executed with the help of a " $12 \mathrm{~cm}$ Nonien Theodolite" (Watzinger/Wulzinger 1921, 2). In conjunction with the above-mentioned plan of the electricity company, acceptable results were achieved. In the same way, numerous narrow side streets and lanes, culde-sacs and paths were surveyed and recorded (Watzinger/Wulzinger 1921, 2). In order to understand the differences in height in the old town, the gradients were continuously observed during the survey of the streets and narrow alleys and estimated approximately every $50 \mathrm{~m}$ according to the difference appearing at the houses. Here, Watzinger and Wulzinger referred to Schäffer, who gave the pavement height ("Pflasterhöhe") at Bâb esch-scharki as $714 \mathrm{~m}$ above sea level and took this figure as a starting point while including other points in the old city as reference points in relation to Schäffer's measurements (Watzinger/Wulzinger 1921, 2-3).
During the survey work, Watzinger and Wulzinger kept looking for structural remains of the ancient and Islamic pasts and paid special attention to individual sites. One place will be discussed here as an example (fig. 9): "On the opposite side of the Sûk tauwîle or midhat-pasha to the west of the Chân ez-zêit, we [Watzinger/Wulzinger, SW] could follow the traces of the ancient road in the courtyard of a dyeing factory. In the walls on the north and south sides of the courtyard, there were column shafts of the two colonnades, four in the north, three in the south; a fourth in the south is no longer in its old place." (Watzinger/Wulzinger 1921, 46). During their stay in Damascus, the two scientists measured the courtyard they visited, noted the exact location of the pillars in their route recording books and drew them in order to be able to present their results in a scientifically adequate way in the later publication.

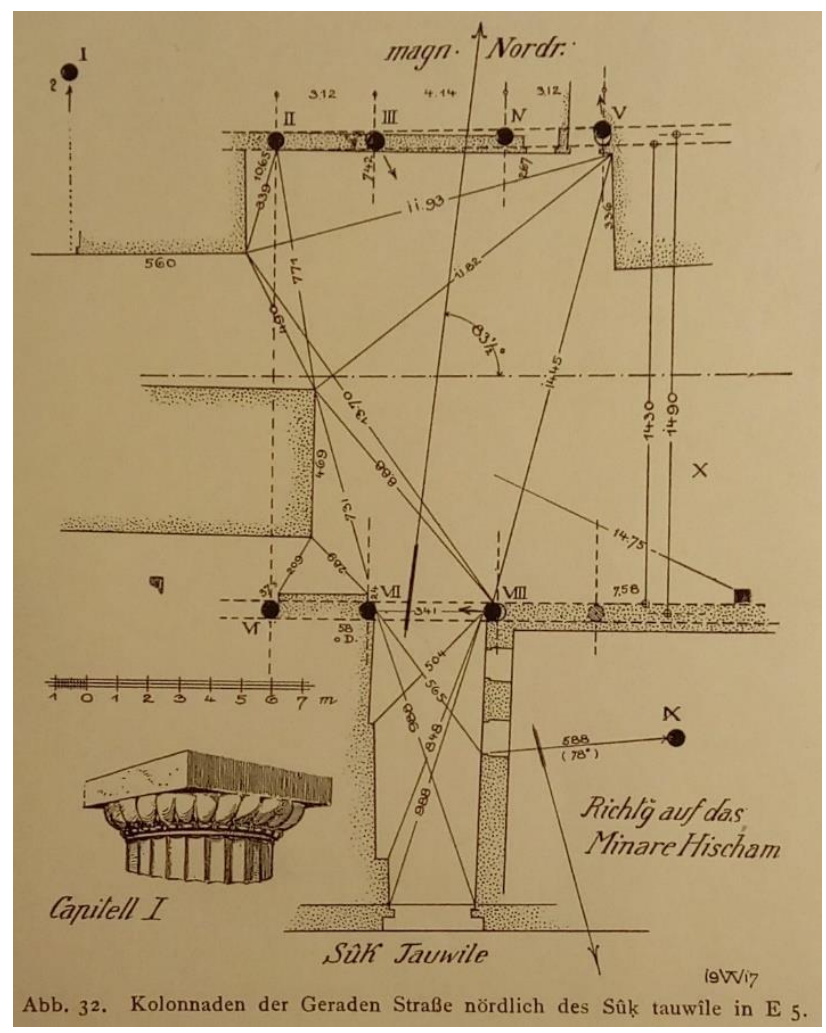

Figure 9: Sketch of Collonades on Straight Street north of Sûk tauwîle (Watzinger/Wulzinger 1921, 46, fig. 32).

They also examined whether the columns were in situ. In the courtyard shown in fig. 3, for example, they noticed that a fifth column shaft in the north, which was used as a central support for a room directly adjacent, was not originally erected for this purpose. Furthermore, Watzinger and Wulzinger had no access to the room itself, but they stated that the design of the capital of the column under discussion did not fit in with the other colonnades (Watzinger/Wulzinger 1921, 46-47). Consequently, both scholars used their stay in Damascus for an intensive study of the ancient and Islamic remains in the city and mapped them as detailed as possible, though they prioritised the study of the ancient architectural remains. While they had already begun to study and record the Greco-roman's 
ancient remains in the city in detail between 1917/18, they initially only recorded the ancient structures of the Islamic period during their stay in Damascus. The records were only to be evaluated at a later date (Wiegand 1924, n.pag.). For the "discovery" of significant Islamic monuments, Watzinger resorted to Jusuf Aghabi, who, according to Wiegand, "found and paved the way to the more remote monuments, made the initial investigation and identification." (Wiegand 1924, n.p.) Watzinger mentioned "Jusuph Aghâbi, an Arab from Jaffa"17 only once in his diary, on the occasion when the latter secured him a corner seat in a train from Jerusalem to Haifa. Wiegand's statement, however, suggests that Watzinger and Wulzinger seemed to be dependent on the help of Jusuf Aghabi with regard to the investigation and recording of Islamic monuments in Damascus. official's room, and with his permission." (Hanauer 1924, 68) Hanauer gives no further details about the building from which he took the plan and who he says gave him permission to do so. We do not know whether Hanauer went to the former Spanish consulate to discover the plan there or whether he found it in another damascene house used by the German military. The map that Hanauer published in the Quarterly Statements was based on the one that Watzinger and Wulzinger had produced during the First World War on behalf of Ahmed Cemal. In the Karl Wulzinger collection in the archive of the German Archaeological Institute in Berlin, the version of the map shown here (fig. 10) bears the title "Plan of the Old City of Damascus. Recorded by order of Dschemal Pascha, by Bureau 19 of the 4th Turk. Army". It illustrates not only that the German scholars devoted themselves to the

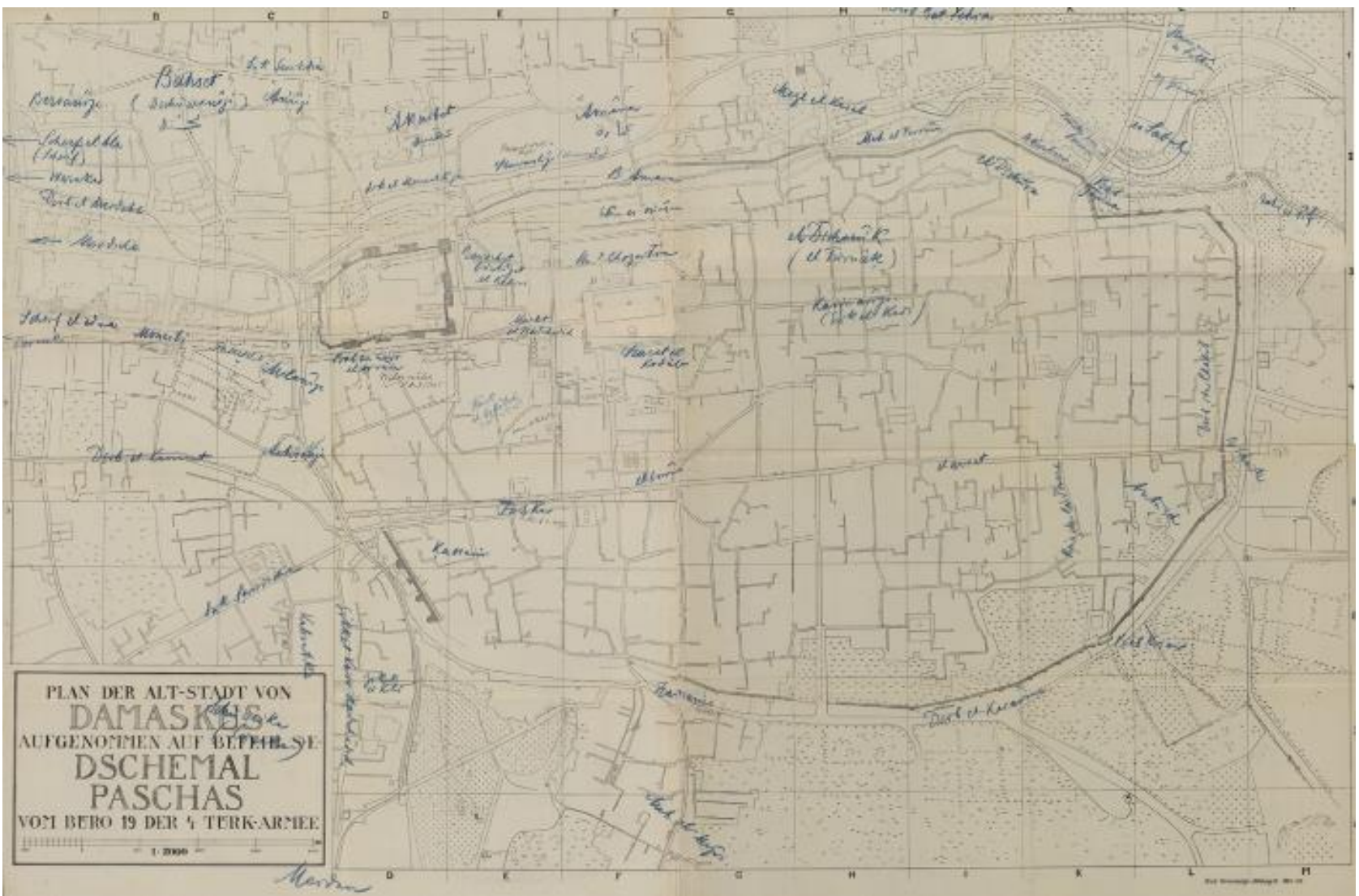

Figure 10: Plan of the old city of Damascus. Recorded by order of His Excellency Jemal Pasha, by Bureau 19 of the 4 . Turk. Army. Scale 1:2000. Courtesy of Deutsches Archäologisches Institut: DAI-Z-AdZ, Collection Wulzinger, Box 8, Folder Damascus.

\section{The Map of the Damascene Old City}

The later Canon of St. George's Cathedral in Jerusalem, James Edward Hanauer (1850-1938), reported in the Palestine Exploration Fund's Quarterly Statements about a discovery he made when entering Damascus in 1918: "In the following I am sending a few notes on the German survey of Damascus. The copy I am sending, from which the accompanying plan is taken, was torn down, on the last day of the German occupation, from the wall of a German creation of the map, as the Ottoman army commander had commissioned them to do so. It also indicates that the institution dealing with the protection of monuments and the mapping of ancient sites did not yet bear the name "German Turkish Commando for Monument Protection" but was simply called "19th Office of the IV Ottoman Army".

Wulzinger's handwritten notes visible on the map mark the location of city gates, individual quarters, or places with a connection to ancient objects or remains discovered by the

17 UAT, 546/2, p. 150, Diary of Carl Watzinger, Entry of 16 March 1917. 
scientists during their tours through the city. As the map illustrates, not all alleys could be traced down to the smallest detail. In their publication, Watzinger and Wulzinger report with reference to the area in the West of the centre "from I 3 to I 4, which contains the second highest and most prominent elevation of the city area, has no streets crossing at right angles at all, but is filled with a restless maze of mostly short alleys" (Watzinger/Wulzinger 1921, 49). The scientists hypothesised that "the complete lack of continuous road lines in this area could perhaps be due to a break in the ancient road course as well" (Watzinger/Wulzinger 1921, 49). From these references, it is already clear that Watzinger and Wulzinger used the map for their own research and, in the post-war period, compared it with the records noted during the war. For the research results written down in the publication on the ancient city of Damascus, the map served as a basis to which Watzinger and Wulzinger frequently referred to in the text of their publications in 1921 and 1924. Besides the abovementioned reference to the absence of rectangular street corners, the scholars defined the highest point of the urban area of Damascus in G 5. The hill was completely occupied by buildings: "At this point, the hitherto usual north-south course of the present cross-streets is abandoned; two lanes extend around the southern slope of the hill; the western one, Tell en-najâr (Carpenter's Hill), goes in an arc to about the middle of the southern foot of the hill; the other eastern one, Tell es-samach (Fish Hill) maintains an oblique direction and joins it south of the bend in the western one. In the aerial photograph of this area [fig. 5], not only the striking course of these two streets, but also the concentric arrangement of the rings of houses between the straight street and the curved side streets stands out clearly. The semicircular shape of the area thus delimited, the central diameter of which is formed by an approximately $120 \mathrm{~m}$ long section of the Straight Street, has such a resemblance to the Koilon of an ancient theatre that Hanauer, who first observed the strange course of the street, already drew the correct conclusion that this place encloses the site of an ancient theatre" (Watzinger/Wulzinger 1921, 44).

Watzinger and Wulzinger based their theses about ancient structures that were still reflected in the urban structure of contemporary Damascus on the surveys they made. They supported their findings with aerial photographs and finally the map they produced. The two scholars proceeded in a similar manner in their investigation of the course of the ancient and Arab city walls: "The present-day Arab city wall stretches along the main branch of the Barada from the northeast corner of the Kal' â to the Bâb essalâme, while the ancient one, according to the location of the arched gate, followed the southern small branch of the river, behind which first the southern Bâb es-salâme also the Arab city wall recedes. There is further evidence of the course of the ancient city wall: the street that runs between the two arms of the Barada towards Bâb es-salâme is still called Bên es-sûrên, (between the walls). In addition to the Arabic city wall in the north, there must have been a second one in the south of the street; when the Arabic name came into being, the ancient wall was obviously still there. Thus, the course of the ancient city wall is in the immediate vicinity of the market, while in Arab times the city area is pushed out to the north. Only south of Bâb es-salâme does the Arab city wall re-join the course of the ancient one" (Watzinger/Wulzinger 1921, 51-52).

During the investigations on the city wall, Watzinger and Wulzinger tried to map the remains of ancient structures. An impression is conveyed from area G 6, located slightly south of the map's centre. Watzinger and Wulzinger reported "a quantity of ancient ashlars lying at the eastern edge of the alley, which must have come from a recently demolished wall, perhaps from the shops in the street; further south an ancient column shaft, which may once have belonged to the colonnade. Remarkable are also the steps in the course of the two southern cross-streets, which lie approximately in the same alignment and are probably caused by the consideration of ancient shop walls that have remained standing. Finally, a find in the southeast corner of $F$ provided complete certainty of the existence of an ancient street alignment. In this area, about $50 \mathrm{~m}$ east of the Arabic Bâb es-saghîr, we noticed a courtyard on the south side of the narrow alley, in addition to several column shafts, numerous ashlars and arched wedge stones, which obviously came from a freshly broken ancient arched gate. It is precisely here at the exit of the northsouth street that one will have to look for an ancient city gate that corresponded to the later Bâb es-saghîr" (Watzinger/Wulzinger 1921, 53).

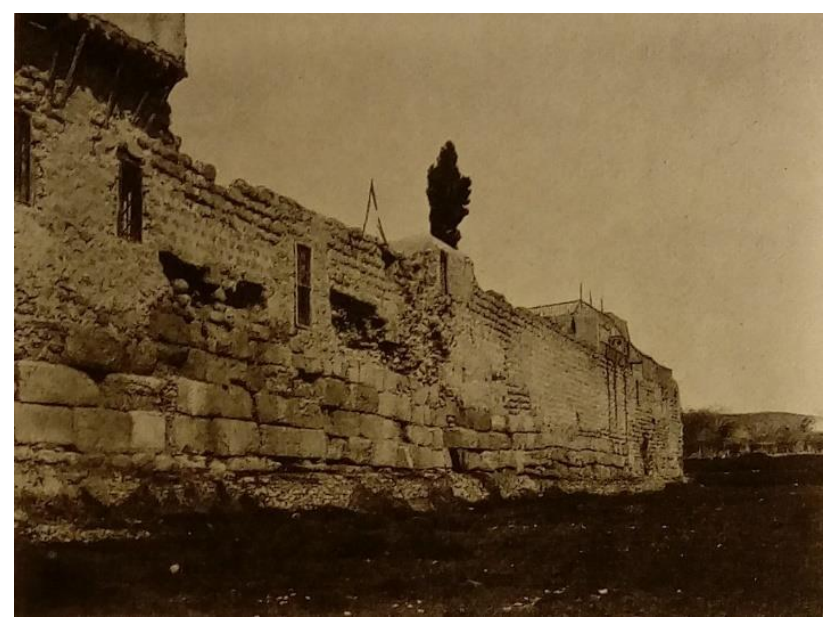

Figure 11: Watzinger and Wulzinger stated in the subtitle: "Arab City Wall with antique ashlar in L 4" (Watzinger/Wulzinger 1921, 58, fig. 35).

Of particular interest for the archaeologists and architects was the intertwining of the ancient with the Arab city wall. In plan square L 4 in the east of the map, Watzinger and Wulzinger examined the ancient and Arab remains of the city wall's structure in detail. To support their research, the scientists not only made use of aerial photographs, but also took ground photographs. In conjunction with the map of the old town drawn between 1917 and 1918, Watzinger and Wulzinger then evaluated their results in Germany at the beginning of the 1920s. As the photograph (fig. 11) vividly shows, the scholars sought to visually record the 
condition of certain sections of the city wall in order to illustrate the extent to which the intertwining of ancient and Arabic structure was still visible. Watzinger and Wulzinger closely studied the depicted area and wrote: "The section of the Arab wall from here to the east gate extends eastwards and shows numerous large ashlars, some in three rows one above the other, and walled column shafts [...]. From the east gate to the south, in the garden of the Armenian patriarchate, there is a wall running in a straight line over a length of about $60 \mathrm{~m}$, the lower part of which is composed of four layers of ancient ashlar work, on which the Arabic wall, consisting of small stones, rises first [...]" (Watzinger/Wulzinger 1921, 57-58). During the war, Wulzinger had surveyed the section of the city wall and used his sketch to support the photograph (fig. 12).

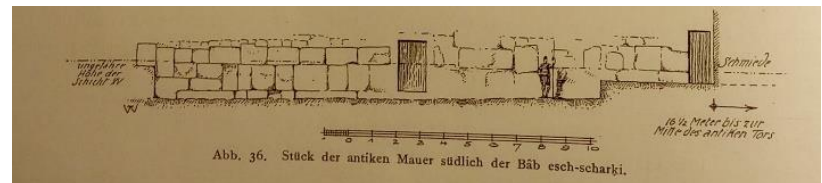

Figure 12: Sketch of the city wall (Watzinger/Wulzinger 1921, 58, fig. 36).

In conjunction with the map of the old town, both the scholars and the reader were enabled not only to determine the exact location of the section of the town wall under study, but also to understand in detail its construction, appearance and condition in 1917/18. Within the city plan, Watzinger and Wulzinger marked certain areas that they defined as ancient walls and distinguished them from parts that were "perhaps Byzantine restored" (Watzinger/ Wulzinger 1921, 58). Already "the Byzantine city exceeded the ancient wall belt" (Wulzinger/Watzinger 1924, 33; Watzinger/Wulzinger 1921, 57). In the northeastern area at L 3 and L 4 they marked the possibly Byzantine restored part of the wall with the help of a dotted line and described that the wall "east of Bâb Tûmâ makes a right angle" and meets an Arab corner tower (Watzinger/Wulzinger 1921, 58). From these descriptions, the scientists concluded that the ancient city wall at this point (K 2-L 2-L 3) had a different course than the Arab Wall: "According to this, it is reasonable to assume that the ancient wall on the east side ran in a straight line from north to south" (Watzinger/Wulzinger 1921, 58).

As has already been apparent, sections considered to be of particular interest were illustrated in the publication by photographs. One example is the Bab Sharqi (fig. 13), which is one of the seven ancient city gates of Damascus. It is the only original gate from Roman times that has survived and borders the Straight Road (Via Recta) to its eastern end. The street itself runs east-west through the old city of Damascus. The course of the Straight Road is shown on the map from Bab Sharqi (L 5) eastwards along to D 5.

Watzinger and Wulzinger examined the urban structure of the old town and searched for clues and features of the Hippodamian system. From the publications, a hierarchisation of the time strata seems to emerge, according to which the ancient period was classified above the Islamic one.

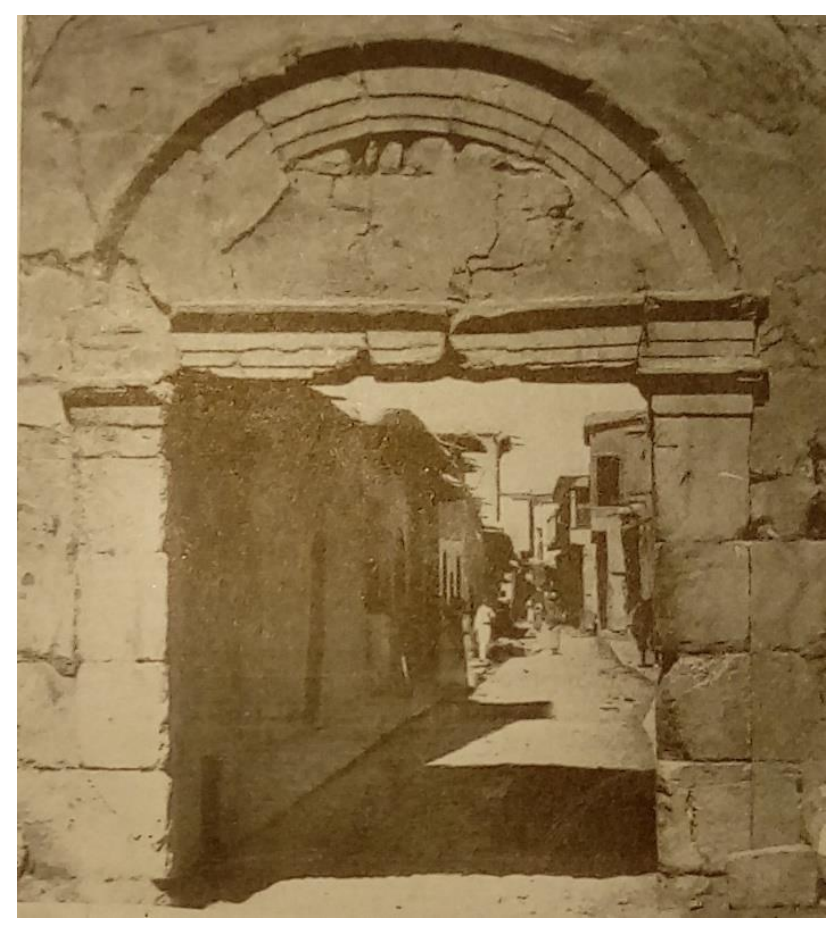

Figure 13: "Bâb esch-scharkị" (Bab Sharqi) in an earlier state (Watzinger/Wulzinger 1921, 69, fig. 40).

As Watzinger and Wulzinger stated: „Within the ancient insulae, some older buildings may have been left untouched by the Hippodamian system. It is highly probable that such influences of the oldest planning have still survived today merely as building lines, but we lack the connections. In general, the Arab overbuilding has 'worm-lined' the inner surfaces of the insulae, where there were not long, fixed alignments, in short-pronged, kinkrich, angular alleys" (Wulzinger/Watzinger 1924, 31).

From the material collected during the First World War, Watzinger and Wulzinger compiled a "Topographical Catalogue of Damascus" (Wulzinger/Watzinger 1924, 46). For the plan, the scholars referred to the map produced in $1917 / 18$ so that the location of the numbered and listed historic buildings can be traced: "In its numbering, the topographical catalogue refers to the plan photographs that provide the basis for all determinations" (Wulzinger/Watzinger 1924, 46). For the areas of Damascus not depicted by Wulzinger and Watzinger, the scholars referred to Bädecker's plans for Palestine or Schäffer's 1913 map (Wulzinger/Watzinger 1924, 46).

While the plan found in the archive has a scale of 1:2.000, Watzinger and Wulzinger used slightly modified plans on a scale of 1: 4.000 for their publications. The plans considered the foothills of the ancient city as well as the immediately adjacent damascene quarters of 1917/18, so they were not exclusively limited to the area intra muros. In the plan "Water supply system of Old Damascus", the fresh water supply and sewers are visualised. Of particular interest is the visualisation of the measured altitude differences of the old city in this map (Wulzinger/Watzinger 1924, ill. 61) as well as in the map published in 1921 (Watzinger/Wulzinger 1921, ill. II). 


\section{Conclusion}

The importance of the maps produced by Watzinger and Wulzinger for research done 90 years after their compilation is made clear by Weber's introduction to the catalogue comprising the inventory of buildings in Damascus and "supplementary information", in which he writes: "As an historical source I have repeatedly referred to the maps compiled by Wulzinger/Watzinger and the various travel guides." (Weber 2009b, 19; See also Weber 2009a, 22). The value of the collected and published material is also illustrated by this contribution. However, it is hardly possible to speak of German-Ottoman cooperation on an equal footing. The German archaeologist's presence in Ottoman Syria during the First World War was viewed critically by the Müze-i Hümayun from the beginning. Although Wiegand, as head of the formation, briefly referred to the "friendly assistance" (Wiegand 1924, n.p.) of the Istanbul museum official Aziz Ogan (1888-1956) and the architect Kazım Tahsin in his acknowledgement in the publication on Islamic Damascus, no further details were given about the assistance or possible cooperation between the German and Ottoman archaeologists in Damascus, as was the case with Jusuf Aghabi, who was only mentioned once by Watzinger. It can be assumed that the German scholars depended on the language and local knowledge of Ottoman assistants, military officers, and scientists in order to gain access to religious buildings or private houses. However, for Watzinger, Wulzinger and Wiegand, it did neither seem worthwhile to acknowledge the support of Ottomans nor to provide a detailed account of it.

Ahmed Cemal pursued infrastructural and urban planning measures to consolidate Syria as an integral part of the Ottoman Empire and to demonstrate his power. In addition to the architectural and infrastructural appropriation of space that Ahmed Cemal planned and partially implemented during the First World War, the past was also to be exploited for his objectives. A detailed map of the old city of Damascus accordingly fits into the interests and objectives of the Young Turk governor-general of Syria outlined by Çelik and Azarbadegan. Maps drawn in the late Ottoman Empire's period were a tool of colonial and imperial ideologies (Çelik/Azarbadegan 2020, 92), consequently leading to an intertwining of empire and geography: "Maps not only depict but construct and project spaces and thus turn spaces into territories in the first place" (Schlögel 2016, 13). Schlögel highlighted, times of war, revolutions or military campaigns mean a significant increase in the distribution of map material (Schlögel 84). The movements of armies or the supply and transport conditions without maps was unthinkable during the First World War. Furthermore, by utilising aerial photographs, an extended range of tools was used to create detailed maps of even unmapped regions. As has been pointed out, these opportunities were used by British troops as well as German and Ottoman units.

However, the map of the old city of Damascus in focus here was not created for military purposes, but was used by German archaeologists for detailed surveying, investigation and mapping of the city and its ancient structures, architectural remains and objects. Especially since Ahmed Cemal left Syria at the end of 1917, he no longer accompanied the completion of the map. There is no evidence of close cooperation between German and Ottoman archaeologists in Damascus. The information and records collected by the members of the 19th Bureau between 1917 and 1918, as well as the material comprising aerial and ground photographs, were only evaluated and published by German scientists in the post-war period. Although Ottoman map material was created and produced before and during the war, German archaeologists did not resort to it.

The addressees of the Wiegand Formation's publication were neither representatives of the Syrian population nor Ottoman scholars. The German scientists were aware of their temporarily limited presence in Syria. Especially their privileged access to ancient sites as well as religious sanctuaries under the patronage of Ahmed Cemal paved their way to primarily pursue their scientific objectives. The scientific appropriation of the damascene space represented the primary interest of Watzinger, Wiegand and Wulzinger. Against the backdrop of German-Ottoman relations in the archaeological field, which had already been shattered before the First World War, the German scholars used their presence in Ottoman Syria to compensate for no longer feasible excavations by carrying out scientific research. During the war, the German scientists collected material to investigate various ancient sites, initiated new research, studied and mapped Damascus in detail with regard to both its ancient and Islamic relics.

Ottoman and German military and administrative officials shared an interest in detailed surveying and mapping in terms of improving infrastructural measures, sanitary situation and the appropriation of space. However, close cooperation was not implemented in the case of Damascus, while the creation of a bilingual map was not the aim of the German scientists involved in the mapping processes.

Under the impression of the changing balance of power in the post-war period, and presumably also with the awareness of the secluded status of the former Ottoman territories, which were easier to visit for German scholars between 1914 and 1918, the German archaeologists Wiegand, Watzinger and Wulzinger evaluated and published the results they had carefully noted during the war period. The material was not only used by the archaeologists of the 19th office, but also by Dalman. The theologian published the aerial photography of the Bavarian Flying-Detachments in 1925 with the remark that these "do not just want to be looked at, but studied in detail" (Dalman 1925, 4).

\section{Acknowledgements}

I owe a great debt of gratitude to Hanswulf Bloedhorn (Tübingen), who provided me with Watzinger's diary and to Zoya Masoud (TU Berlin) for the damascene insights. 


\section{References}

Alt, Albrecht (1920): Aus der Kriegsarbeit der deutschen Wissenschaft in Palästina. In: Zeitschrift des Deutschen Palästina-Vereins, Bd. 43, H. 3/4, pp. 93-108.

Baumgart, Winfried (ed.) (2020): Friedrich Freiherr Kreß von Kressenstein. Bayerischer General und Orientkenner. Lebenserinnerungen, Tagebücher und Berichte 1914-1946, Paderborn: Ferdinand Schöningh.

Boelcke, Siegfried (1921): Das Kartenwesen. In: Schwarte, Max (ed.): Der Weltkampf um Ehre und Recht. Die Organisationen der Kriegführung, Leipzig

Çelik, Zeynep (2011): Defining Empire's Patrimony: Late Ottoman Perceptions of Antiquities, in: Bahrani, Zainab/Çelik, Zeynep/Eldem, Edhem (eds.): Scramble for the Past. A Story of Archaeology in the Ottoman Empire 1753-1914, İstanbul: Salt, pp. 443-478.

Çelik, Zeynep/Azarbadegan, Zeinab (2020): Late Ottoman Visions of Palestine. Railroads, Maps, and Aerial Photography, in: The Jerusalem Quarterly. Palestine from Above. Surveillance, Cartography and Control, Part II, Issue 82, pp. 87-109.

Cemal Paşa (1922): Hâtırat: 1913-1922, İstanbul.

Cengizkan, Ali (2009): Mimar Kemalettin ve Çağı. Mimarlık/Toplumsal Yaşam/Politika, İstanbul: TMOBB Mimarlar Odası Yayınları.

Çiçek, M. Talha (2014): War and State Formation in Syria. Cemal Pasha's Governorate during World War I, 19141917, New York: Routledge.

Espenhorst, Jürgen (2016): A Good Map is Half the Battle! The Military Cartography of the Central Powers in World War I, in: Liebenberg, Elri/Demhardt, Imre Josef/Vervust, Soetkin (eds.): History of Military Cartography. Lecture Notes in Geoinformation and Cartography, Cham: Springer, pp. 83-130.

Fickeler, Paul (1935): Albert Tafel als deutscher Forschungsreisender. In: Geographische Zeitschrift, vol. 41, Issue 12, pp. 480-484.

Filistin Risalesi (1331/1915). Jerusalem: Kolordu Matbaasi.

Hamshaw, Thomas H. (1920): Geographical Reconnaissance by Aeroplane Photography, with Special Reference to the Work Done on the Palestine Front, in: The Geographical Journal, Vol. 55, No. 5 (May), pp. 349-370.

Hanauer, James Edward (1924): Damascus. Notes on changes Made in the City during the Great War, in: Palestine Exploration Fund. Quarterly Statement, vol. 56, Issue 2, pp. 68-78.

Kayal1, Hasan (1998): Jön Türkler ve Araplar. Osmanlıcılık, Erken Arap Milliyetçiliği ve İslamcılık (1908-1918), İstanbul: Tarih Vakfı Yurt Yayınları.

Kiesling, Hans von (1919): Damaskus. Altes und Neues aus Syrien, Leipzig: Dieterich'sche Verlagsbuchhandlung.
Köksal, Yonca (2006): Coercion and Mediation: Centralization and Sedentarization of Tribes in the Ottoman Empire. In: Middle Eastern Studies, Vol. 42, No. 3, pp. 469-491.

Low, Michael Christopher (2020): Imperial Mecca. Ottoman Arabia and the Indian Ocean Hajj, New York: Columbia University Press.

Marchand, Suzanne L. (1996): Down from Olympus. Archaeology and Philhellenism in Germany, 1750-1970, New Jersey: Princeton University Press.

Theunissen, H. (2016): War, Propaganda and Architecture: Cemal Pasha's Restoration of Islamic Architecture in Damascus during World War I, in: Zürcher, E. J. (ed.): Jihad and Islam in World War I. Studies on the Ottoman Jihad on the Centenary of Snouck Hurgronje's >Holy War Made in Germany<, Leiden 2016, pp. 223-273.

Shaw, Wendy M. K. (2003): Museums and Narratives of Display from the Late Ottoman Empire to the Turkish Republic. In: Muqarnas: An Annual on the Visual Culture of the Islamic World, vol. 24, pp. 253-279.

Shaw, Wendy M. K. (2003): Possessors and Possessed: Museums, Archaeology, and the Visualization of History in the Late Ottoman Empire, Berkeley: University of California Press.

Schlögel, Karl (2016): Im Raum lesen wir die Zeit. Über Zivilisationsgeschichte und Geopolitik, Frankfurt am Main: Fischer.

Tamari, Salim (2011a): Shifting Ottoman Conceptions of Palestine. Part 1: Filistin Risalesi and the two Jamals, in: Jerusalem Quarterly, Issue 47, pp. 28-38.

Tamari, Salim (2011b): Shifting Ottoman Conceptions of Palestine. Part 2: Ethnography and Cartography, in: Jerusalem Quarterly, Issue 48, pp. 6-16.

Waldenfeld, Otto von (1925): Die Bayerische FliegerAbteilung 304 in Palästina 1917/18. In: Dalman, Gustaf (eds.): Hundert Deutsche Fliegerbilder aus Palaestina. Gütersloh: Bertelsmann, pp. 120-123.

Watzinger, Carl/Wulzinger, Karl (1921): Damaskus. Die antike Stadt, Berlin/Leipzig: De Gruyter.

Weber, Stefan (2009a): Damascus. Ottoman Modernity and Urban Transformation (1808-1918), Vol. I: Text, Proceedings of the Danish Institute of Damascus V. Aarhus: Aarhus University Press.

Weber, Stefan (2009b): Damascus. Ottoman Modernity and Urban Transformation (1808-1918), Vol. II: Catalogue, Proceedings of the Danish Institute of Damascus V. Aarhus: Aarhus University Press.

Wiegand, Theodor (1919): Denkmalschutz und kunstwissenschaftliche Arbeit während des Weltkrieges in Syrien, Palästina und Westarabien. In: Clemen, Paul (ed.): Kunstschutz im Kriege. Berichte über den Zustand der Kunstdenkmäler auf den verschiedenen Kriegsschauplätzen und über die deutschen und österreichischen Massnahmen zu ihrer Erhaltung, Rettung und Forschung, Zweiter Band: Die 
Kriegsschauplätze in Italien, im Osten und Südosten, Leipzig: Seemann, pp. 174-190.

Wiegand, Theodor (ed.) (1920): Sinai. Wissenschaftliche Veröffentlichungen des Deutsch-türkischen Denkmalschutz-Kommandos, Heft 1, Berlin/Leipzig: De Gruyter.

Wiegand, Theodor (1921): Vorwort. In: Watzinger, Carl/Wulzinger, Karl: Damaskus. Die antike Stadt, Berlin/Leipzig: De Gruyter, p. 5.

Wiegand, Theodor (1924): Vorwort. In: Wulzinger, Karl/Watzinger, Carl: Damaskus. Die islamische Stadt
(Wissenschaftliche Veröffentlichungen des Deutschtürkischen Denkmalschutz-Kommandos ed. Theodor Wiegand, vol. 5), Berlin/Leipzig: De Gruyter, n.p.

Wulzinger, Karl/Watzinger, Carl (1924): Damaskus. Die islamische Stadt (Wissenschaftliche Veröffentlichungen des Deutsch-türkischen Denkmalschutz-Kommandos ed. Theodor Wiegand, vol. 5), Berlin/Leipzig: De Gruyter.

Yazbak, Mahmoud (2017): The Birth of the Jerusalem Sanjak 1861-1914: Administrative and Social Impacts. In: BPS-Bulletin of Palestine Studies, Jerusalem Special Issue 2, pp. 32-57. 